\title{
Kewenangan Dokter Spesialis Dalam Melakukan Tindakan Medis Di Klinik Utama Rawat Inap
}

\author{
Ns. Pamuji ${ }^{1}$, M. Khoirul Huda ${ }^{2}$ \\ ${ }^{1}$ Mahasiswa Program Pascasarjana Ilmu Hukum, Universitas Hang Tuah Surabaya, Jl. Gadung No. 1 Kompleks Barat RSAL \\ dr. Ramelan, Surabaya, 60111 \\ E-mail: yepahusadakaibon@yahoo.co.id \\ ${ }^{1}$ Dosen Pascasarjana Ilmu Hukum, Universitas Hang Tuah Surabaya, Jl. Gadung No. 1 Kompleks Barat RSAL dr. Ramelan, \\ Surabaya, 60111 \\ E-mail: yepahusadakaibon@yahoo.co.id
}

\begin{abstract}
Every citizens have the same right to access the health service in the form of promotive, preventive, curative, and rehabilitative which facilities are held by the government, the local government, and the society including the primary clinic. A specialist doctor in the inpatient primary clinic has atributive, mandatory, and delegative authority based on the education standard, competency, profesional standard, and operational procedure standard. The primary clinic can conduct the mild and moderate surgery with general anesthesia. However, there is a contradiction between two regulations that later limits the authority of the specialist doctor and the anesthesia doctor to conduct the surgery. A specialist doctor in carrying out their authority should consider the operational standard, informed consent, ethical code, and the hospital by law. Along with the authority, the doctor also has a huge responsibility to treat the patients based on the procedure both legally and ethically as detemined. The previous regulation, Health Ministry Regulation of the Republic of Indonesia article 9 year 2014 about clinic, has not enacted firmly about the specialist doctor's authority in the inpatient primary clinic. The specialist doctors have legal responsibility, profesional responsibility, ethical and discipline responsibility, criminal law responsibility, civil law responsibility, and administrative law responsibility Therefore, we recommend to conduct a judicial review on Health Ministry Regulation of the Republic of Indonesia article 9 year 2014 about the specialist doctor's authority.
\end{abstract}

Keywords—: inpatient primary clinic; specialist doctor's authority; specialist doctor's responsibility.

\section{PENDAHULUAN}

\section{A. Latar Belakang}

Setiap orang berhak hidup sejahtera lahir dan batin, bertempat tinggal, dan mendapatkan lingkungan hidup yang baik dan sehat serta berhak memperoleh pelayanan kesehatan menurut Undang-Undang Dasar ( UUD ) 1945 pasal 28 H (1). Hal ini menunjukan bahwa pemerintah berkewajiban menyehatkan yang sakit dan berupaya mempertahankan yang sehat tetap sehat. Peraturan Menteri Kesehatan Republik Indonesia (PMK) Nomor 71 tahun 2013 Tentang Pelayanan Kesehatan pasal 1 (5) menyebutkan bahwa Fasilitas Kesehatan adalah fasilitas yang digunakan untuk menyelenggarakan upaya pelayanan kesehatan perorangan baik promotif, preventif, kuratif maupun rehabilitatif yang dilakukan oleh Pemerintah, Pemerintah Daerah, dan /atau Masyarakat. Pelayanan kesehatan pada sistem JKN telah diatur di PMK tentang pelayanan JKN pasal 2 ayat (3) bahwa fasilitas kesehatan tingkat lanjutan yang dimaksud adalah klinik utama, rumah sakit, dan rumah sakit khusus. Pada PMK Republik Indonesia Nomor 9 tahun 2014 tentang Klinik pasal 2 ayat (3) Klinik Utama merupakan klinik yang menyelenggarakan pelayanan medik spesialistik atau pelayanan medik dasar dan spesialistik. Pada penyelenggaraanya pada pasal 34 ayat (2) a; bahwa klinik utama dapat melakukan tindakan bedah kecuali tindakan bedah yang menggunakan anaestesi umum dengan inhalasi dan/atau spinal, poin b; operasi sedang yang berisiko tinggi dan c; operasi besar.

Undang-Undang Praktek Kedokteran tahun 2004 pasal 35 bahwa dokter dan dokter gigi yang memiliki surat tanda registrasi (STR) mempunyai wewenang melakukan praktek kedokteran sesuai dengan pendidikan dan kompentensi yang dimiliki. Terdapat kontroversi pada implementasi tindakan dokter spesialis bedah dan dokter spesialis anestesi. Tindakan dokter spesialis bedah dalam mengerjakan tindakan bedah ringan menggunakan anestesi umum supaya dalam mengerjakan tindakan bedah lebih aman dan nyaman. Namun, PMK tentang Klinik menyebutkan bahwa dokter anestesi tidak diperbolehkan untuk melakukan anestesi umum dan spinal, yang juga berlaku pada dokter spesialis yang lainnya. Dokter merupakan profesi yang mempunyai tanggung jawab secara hukum dalam melaksanakan tindakan kedokteran. Tanggung jawab ini sangat tergantung pada kesesuaian tindakan dokter terhadap prosedur baik secara etik maupun secara hukum. Apabila tindakan tersebut berkaitan dengan pelanggaran di bidang hukum perdata, maka pasien yang merasa di rugikan akan menuntut gugatan secara perdata. Apabila pelanggaran tersebut menyangkut badan dan jiwa pasien, maka pasien dapat mengajukan tuntutan secara pidana kepada pihak-pihak yang berwenang. PMK Republik Indonesia tentang Klinik belum mengatur dengan tegas kewenangan tindakan

\footnotetext{
${ }^{1}$ Muhamad Sadi Is, Etika dan Hukum Kesehatan, Kencana Prenadamedia Group, Jakarta, 2015, h. 7
} 
dokter spesialis di klinik utama rawat inap baik melalui Konsil Kedokteran Indonesia (KKI) maupun di organisasi profesi kedokteran Indonesia.

Undang - Undang No. 36 Tahun 2009 Tentang Kesehatan Pasal 14 (1) Pemerintah bertanggung jawab merencanakan, mengatur, menyelenggarakan, membina, dan mengawasi penyelengaraan upaya kesehatan yang merata dan terjangkau oleh masyarakat. Dalam kurun waktu lima tahun terakhir terjadi peningkatan jumlah puskesmas yang secara tidak secara langsung menggambarkan kebutuhan pelayanan kesehatan primer di suatu wilayah. ${ }^{2}$ Pemenuhan kebutuhan puskesmas telah terpenuhi secara nasional. Meskipun demikian, jumlah penduduk tiap kecamatan tidak merata sehingga satu puskesmas dalam satu kecamatan belum mewakili pemerataan sarana pelayanan kesehatan. Maka dari itu peran swasta penting dalam pemenuhan sarana fasilitas kesehatan yaitu dengan berdirinya klinik - klinik swasta sangat diharapkan oleh pihak pemerintah. ${ }^{2}$

Terdapat keterbatasan jumlah dokter spesialis di kota maupun kecamatan. Keterlibatan klinik utama rawat inap dengan pelayanan dokter spesialis dan dokter sub spesialis dapat menciptakan paradigma baru dengan fasilitas kesehatan yang dilengkapi instrumen sarana prasarana dan sumber daya tenaga kesehatan. Hal ini berlaku juga pada ketersediaan sumber daya tenaga kesehatan yaitu dokter spesialis secara merata di setiap kecamatan yang dapat memberikan pelayanan yang maksimal. Perizinan klinik utama rawat inap lebih mudah diurus dibandingkan dengan perizinan rumah sakit. Hal ini akan mengubah mindset para pengusaha swasta untuk bergerak di bidang klinik utama rawat inap. Terlebih, dokter spesialis yang termasuk tenaga kesehatan mendapatkan kepastian dan perlindungan hukum dalam menjalankan tugasnya. Hal ini diatur dalam UndangUndang (UU) Nomor 36 Tahun 2009 tentang Kesehatan pasal 27 ayat 1. Hal ini tentunya akan mendorong profesi dokter spesialis akan menjadi lebih baik dalam mengabdikan dirinya pada masyarakat dan negara.

\section{B. Kerangka Teori}

Kewenangan seorang tenaga kesehatan adalah kewenangan hukum (rechtbevoegheid) yang dimiliki oleh seorang tenaga kesehatan untuk melaksanakan pekerjaanya dan kemampuan untuk mempengaruhi pihak lain yang disahkan oleh yang berhak mengesahkan. ${ }^{3}$ Kewenangan yang sah bila ditinjau dari sumber dari mana kewenangan itu lahir atau diperoleh, maka terdapat tiga kategori kewenangan, yaitu atributif, mandat, dan delegatif. ${ }^{4}$ Dalam kewenangan atributif pelaksanaannya dilakukan sendiri oleh pejabat atau badan tersebut tertera dalam peraturan dasarnya. Mandat adalah suatu pelimpahan wewenang kepada bawahan. Pelimpahan itu bermaksud memberi wewenang kepada bawahan untuk membuat keputusan atas nama (a.n) pejabat Tata Usaha Negara yang memberi mandat. Delegasi adalah penyerahan wewenang yang dipunyai oleh organ pemerintahan kepada organ yang lain. Dalam delegasi mengandung suatu penyerahan, yaitu apa yang semula kewenangan si A, untuk selanjutnya menjadi kewenangan si B. Kewenangan yang telah diberikan oleh pemberi delegasi selanjutnya menjadi tanggung jawab penerima wewenang.

Seorang dokter dalam melaksanakan pelayanan terhadap pasien harus sesuai kompetensinya dan bekerja sesuai dengan kode etik. Teori pertanggungjawaban Muntaha dalam konsep Roscoe Pound mengartikan Liability adalah suatu kewajiban untuk membayar pembalasan yang akan diterima pelaku dari seorang yang telah dirugikan. Hal ini dimaksudkan, pelayanan yang diberikan sesuai dengan Standar Kompetensi Dokter Indonesia, tanggung jawab ditunjukan dengan cara siap menerima hukuman (punishment) secara hukum kalau seorang dokter terbukti bersalah atau melanggar hukum. Pertanggungjawaban hukum seorang dokter dapat dilihat berdasarkan tiga bentuk pembidangan hukum secara perdata, pidana, dan administrasi. Secara prinsip pertanggungjawaban hukum administrasi lahir karena adanya pelanggaran terhadap ketentuan hukum administrasi terhadap penyelenggara izin praktek dokter terhadap ketentuan yang berlaku. Menurut Ridwan Syahrani yang dimaksud dengan hukum perdata adalah hukum yang mengatur hubungan hukum antara orang yang satu dengan orang yang lain di dalam masyarakat yang menitik beratkan kepada kepentingan perseorangan (pribadi). ${ }^{5}$ Aspek pertanggungjawaban secara hukum pidana seorang dokter baru dapat dimintai pertanggungjawaban apabila terdapat unsur- unsur sebagai berikut ${ }^{6}$

1. Suatu perbuatan yang melawan hukum dalam hal ini apabila dokter melakukan pelayanan kesehatan diluar wewenang yang tertuang pada Permenkes Nomor 2052/MENKES/PER/X/2011 tentang Izin Praktek dan pelaksanaan Praktik Kedokteran .

2. Mampu bertanggungjawab dalam hal ini seorang dokter yang memahami konsekuensi dan risiko dari setiap tindakan dan secara kemampuan telah mendapat pelatihan dan pendidikan, artinya seorang dokter yang menyadari bahwa tindakanya dapat merugikan pasien.

3. Adanya kesalahan (schuld) berupa kesengajaan (dolus) atau karena kealpaan (culpa) kesalahan disini bertanggung pada niat (sengaja) atau karena lalai.

4. Tidak adanya alasan pembenar atau alasan pemaaf. Dalam hal ini tidak ada alasan pemaaf seperti tidak adanya aturan yang mengijinkan melakukan suatu tindakan, atau tidak alasan pembenar.

Menurut Pasal 1 butir (1) PMK No. 9 Tahun 2014 tentang Klinik, pengertian klinik yaitu, sebagai berikut : Klinik adalah fasilitas pelayanan kesehatan yang menyelenggarakan pelayanan kesehatan perorangan yang menyediakan pelayanan medis

\footnotetext{
${ }^{2}$ Kementerian Kesehatan Republik Indonesia, Profil kesehatan Indonsia tahun 2016, Jakarta, Kementerian Kesehatan Republik Indonesia. 2017 , h.75

${ }^{3}$ Muntaha, Hukum Pidana Malpraktek Pertanggungjawaban dan penghapus Pidana, Sinar Grafika, Jakarta Timur , 2017, h.53

${ }^{4}$ Lutfi Effendi, Pokok-pokok Hukum Administrasi, Cetakan III, Bayumedia, Malang, 2004, h .77- 79.

${ }^{5}$ Ridwan Syahrani, Seluk Beluk dan Asas-Asas Hukum Perdata, Bandung, Cet 4, Pt.Alumni, 2000, h. 2.

${ }^{6}$ Sri Supraptiningsih, Kedudukan Hukum Perawat dalam Upaya Pelayanan Kesehatan di Rumah Sakit.

Rajagrafindo Persada, Jakarta, 2006, h 126.
} 
dasar dan/atau spesialistik. Klinik dapat diselenggarakan oleh pemerintah, pemerintah daerah atau masyarakat. Dalam penyelenggaraannya sesuai dengan Keputusan Menteri Kesehatan, pelayanan kesehatan klinik bersifat promotif, preventif, kuratif dan rehabilitatif.

\section{Metode Penelitian}

\section{Tipe Penelitian}

Tipe penelitian ini merupakan penelitian yuridis normatif yaitu penelitian yang membahas doktrin-doktrin atau asas-asas dalam ilmu hukum, dengan mencari pemecahan atas isu hukum untuk mengadakan identifikasi terhadap pengertian pokok dasar hak dan kewajiban, peristiwa hukum, hubungan hukum dan objek hukum. Penelitian ini mengkaji pada norma-norma hukum yang terdapat dalam peraturan perundang-undangan tertentu secara hukum tertulis dan sistematis. ${ }^{7}$ Dalam penelitian ini, peneliti mengkaji pada norma-norma hukum yang terdapat dalam peraturan perundang-undangan secara sistematis dan putusan pengadilan yang berkaitan dengan pertanggungjawaban pidana. ${ }^{8}$

\section{Pendekatan Masalah}

Pendekatan yang digunakan dalam penelitian ini adalah pendekatan perundang-undangan (statute approach) yaitu pendekatan yang mengkaji tentang asas-asas hukum, norma-norma hukum dan peraturan perundang-undangan serta pendekatan konseptual (conceptal approach) yaitu mengadakan identifikasi terhadap pengertian-pengertian pokok dasar dalam hukum yakni subyek hukum, hak dan kewajiban, peristiwa hukum, hubungan hukum dan obyek hukum. ${ }^{9}$

\section{PEMBAHASAN}

\section{A. Kewenangan Dokter Spesialis Dalam Melakukan Tindakan Medis Di Klinik Utama Rawat Inap}

Kewenangan dokter spesialis dalam melakukan tindakan medis harus berprinsip dasar etika kedokteran yang meliputi prinsip tidak merugikan (nonmaleficence), berbuat baik atau bermanfaat (beneficence), menghormati otonomi pasien (autonomy), dan berkeadilan (juctice). Menurut PMK Nomor 2052 tentang Ijin Praktek Kedokteran Tahun 2011 pasal 3 (3) bahwa kewenangan pendidikan dokter spesialis ditetapkan oleh ketua program studi pendidikan dokter spesialis.

Menurut Bagir Manan wewenang dalam bahasa hukum tidak sama dengan kekuasaan. Kekuasaan hanya menggambarkan hak untuk berbuat dan tidak berbuat.Wewenang sekaligus berarti hak dan kewajiban. Berdasarkan definisi kewenangan menurut para ahli bahwa dokter dalam menjalankan tugasnya sebagai profesi dokter spesialis berdasarkan peraturan perundang - undangan yang berlaku saat ini. Kewenangan altribusi merupakan pemberian kewenangan kepada badan dan/atau pejabat pemerintahan oleh Undang-Undang Dasar Negara Republik Indonesia tahun 1945 atau Undang-Undang.

Kewenangan secara altribusi oleh seorang tenaga medis dalam menjalankan tugas profesinya untuk melakukan pelayanan terhadap pasien. Dalam hal ini seorang dokter berhak melakukan pelayanan kedokteran sesuai dengan keahlianya dan bidang keilmuanya yang diatur pada Undang-Undang Praktek Kedokteran Nomor 9 tahun 2004. Pada pasal 29 ayat (2) bahwa surat tanda registrasi dokter dan surat tanda registrasi dokter gigi diterbitkan oleh Konsil Kedokteran Indonesia. Berdasarkan ketentuan tersebut diatas, dokter secara administrasi telah diberi kewenangan untuk menjalankan tindakan medis sesuai profesi yang diembanya untuk melakukan pelayanan medis kepada pasien dan masyarakat sesuai bidang keilmuannya.

Leenen dan Van der Mijn, ahli hukum kesehatan Belanda, berpendapat bahwa dalam melaksanakan profesinya, seorang tenaga kesehatan perlu berpegang pada tiga ukuran yaitu; kewenangan, kemampuan rata-rata, ketelitian yang umum. ${ }^{10}$ Menurut sifatnya bahwa landasan kewenangan dapat di bedakan menjadi dua bagian yang merupakan satu kesatuan yang tidak dapat dipisahkan.Kewenangan berdasarkan keahlian yang dimiliki oleh seorang dokter dapat diartikan kewenangan material, yaitu melekat pada diri dokter itu setelah menyelesaikan pendidikan dokter yang telah di sumpah jabatan serta memiliki STR dan SIP dokter. Kewenangan menurut ketentuan peraturan perundang undangan disebut kewenangan formal. Dua kewenangan tersebut diatas harus dimiliki oleh seorang dokter.

Consent berarti persetujuan sedangkan, informed adalah telah diinformasikan. Informed consent dapat didefinisikan sebagai persetujuan atas dasar informasi sebagai alat penenentuan nasib sendiri yang berfungsi dalam praktik dokter. Dalam perjanjian terapeutik antara pasien dan dokter gigi maka para pihak harus sepakat tentang upaya pengobatan atau pelayanan kesehatan yang diberikan dokter atau dokter gigi. ${ }^{11}$ Menurut Salgo Leland dikutip dalam buku Guwandi seorang dokter melanggar kewajiban terhadap pasiennya dan bertanggung jawab apabila ia menahan fakta-fakta atas dasar yang sebenarnya pasien akan memberikan persetujuan, dokter tidak boleh memperkecil suatu bahaya yang diketahui atas suatu prosedur atau operasi agar sang pasien mau memberikan persetujuan. ${ }^{12}$

Undang-undang Nomor 44 Tahun 2009 Tentang Rumah Sakit pasal 29 (1) menyatakan bahwa rumah sakit harus menyusun dan melaksanakan peraturan internal rumah sakit (Hospital By Laws). HBL adalah Suatu produk hukum yang merupakan

\footnotetext{
${ }^{7}$ H.Zainudin Ali,M.A, Metode Penelitian Hukum ,Sinar Grafika . Jakarta 2015 h. 25-26

${ }^{8}$.Mertokusumo Sudikno, Penemuan Hukum, Liberty, Yogjakarta 2007, h.18.

${ }^{9}$. Marzuki Peter Mahmud, Penelitian Hukum, Kencana Prenada Media Group, Jakarta 2005, h.59-60.

${ }^{10}$ Wila Chandrawila Supriadi, Hukum Kedokteran,.Mandar Maju .Bandung .2001. h 5

${ }^{11}$ Ibid. h. 104

${ }^{12}$ J. Guwandi, Hukum Medik (Medical Law), Fakulatas Kedokteran Universitas Jakarta, 2004. h. 225.
} 
anggaran rumah tangga FKTL yang di tetapkan oleh pemilik FKTL atau yang mewakili mengatur tugas, peran, kewenangan pemilik untuk peran, tugas, dan kewenangan direktur FKTL, organisasi staf medis, peran, tugas dan kewenangan staf medis. ${ }^{13}$

Dokter spesialis yang berpraktek di klinik utama rawat inap harus mempunyai surat tanda registrasi (STR) dan surat ijin praktek (SIP) sesuai peraturan perundang - undangan. Apabila dokter spesialis yang praktek di klinik utama rawat inap yang telah memiliki STR dan SIP secara altributif telah mempunyai kewenangan dalam melakukan tindakan medis. Klinik utama yang memiliki alat medis telah memenuhi persyaratan dalam PMK tersebut sehingga dokter spesialis mempunyai kewenangan untuk melakukan tindakan medis sesuai dengan kewenangan altribusi dan sesuai keahlian serta kopetensi yang di miliki oleah dokter spesialis tersebut. PMK tahun 2014 pasal 33 ayat (1) mengatur bahwa klinik rawat inap hanya dapat memberikan pelayanan paling lama 5 ( lima ) hari pada ayat (2) mewajibkan bahwa apabila memerlukan rawat inap lebih dari 5 (lima ) hari , maka pasien secara terencana di rujuk di rumah sakit sesuai ketentuan peraturan perundang undangan.

Pada penjelasan di atas peneliti menganalisis pada pasal tersebut diatas, bahwa pasien yang di rawat di klinik utama rawat inap paling lama 5 (lima ) hari, hal tersebut sangat bertentangan dengan UU Praktek Kedokteran dan UU Rumah Sakit serta PMK yang mengatur sistem rujukan perorangan. Telah di jelaskan bahwa sistem pengaturan rujukan dilakukan apabila pasien membutuhkan pelayanan spesialistik atau sub spesialistik dan klinik utama rawat inap tidak dapat memberikan pelayanan kesehatan sesuai dengan kebutuhan pasien karena keterbatasan fasilitas, peralatan dan ketenagaan. Kementerian Kesehatan Indonesia perlu mengatur kewenangan dokter spesialis dan kewenangan klinik utama rawat inap dalam memberikan pelayanan pada pasien. Ketersediaan alat medis dan non medis di klinik utama serta ketersedianya tenaga dokter sebagai klasifikasi klinik utama dalam memberi pelayanan kesehatan kepada pasien. Kewenangan tindakan medis pada klinik utama perlu lebih lanjut diatur agar tidak terjadi tumpang tindih sehingga dapat menghindari pelanggaran wewenang dalam melaksanakan tindakan medis.

Tindakan pembedahan merupakan salah satu pelayanan kesehatan yang beresiko tinggi dan rawan untuk terjadinya perbuatan melawan hukum. PMK Nomor 9 tahun 2014 pasal 34 ayat ( 2 ) bahwa klinik utama dapat melakukan tindakan bedah, kecuali tindakan bedah yang; a) menggunakan anaestesi umum dengan inhalasi dan/atau spinal; b) Operasi sedang yang beresiko tinggi; c) operasi besar. Ayat (3) menyebutkan bahwa klasifikasi bedah kecil, sedang, dan besar di tetapkan oleh organisasi profesi yang bersangkutan. Kewenangan klinis perlu dibedakan dari kewenangan dokter sebagai tenaga kesehatan yang terkandung dalam UU Kesehatan, maupun UU Praktik Kedokteran.

Pasal 34 PMK tentang Klinik bahwa klinik utama dapat melakukan tindakan bedah, kecuali tindakan bedah yang menggunakan anaestesi inhalasi dan /atau spinal. Menurut pandangan peneliti setelah menganalisis UU Praktek Kedokteran dan PMK tentang Klinik seharusnya pihak organisasi profesi Ikatan Dokter Indonesia (IDI) bekerja sama dengan dinas kesehatan sebagai lembaga pemberi izin operasional klinik utama dan surat izin praktek dokter. Dengan demikian, kolegium dokter anestesi dan kolegium dokter bedah, secara peraturan Menteri Kesehatan dan keputusan IDI, menetapkan jenis tindakan ringan, sedang, dan berat yang harus dilakukan oleh dokter spesialis dalam melakukan tindakan medis di klinik utama rawat inap.

\section{B. Tanggung Jawab Dokter Spesialis Dalam Melakukan Tindakan Medis Di Klinik Utama Rawat Inap}

Dokter spesialis dalam melakukan tindakan medis memiliki tanggung jawab secara administrasi, hukum pidana, hukum perdata, hukum profesi, dan etik. Dalam kamus hukum terdapat dua istilah pertanggungjawaban yaitu, liability dan responsibility. Liability merupakan istilah hukum yang luas yang merujuk pada hampir semua karakter risiko atau tanggung jawab, yang pasti, yang bergantung atau yang mungkin meliputi semua karakter hak dan kewajiban secara aktual atau potensial seperti kerugian, ancaman, kejahatan, biaya atau kondisi yang menciptakan tugas untuk melaksanakan undang-undang. Responsibility berarti hal yang dapat dipertanggungjawabkan atas suatu kewajiban, dan termasuk putusan, ketrampilan, kemampuan dan kecakapan meliputi juga kewajiban bertanggung jawab atas undang-undang yang dilaksanakan.

Dokter spesialis dalam melaksanakan wewenang dan profesinya harus berpegang teguh pada tiga ukuran meliputi kewenangan, kemampuan rata - rata dan ketelitian yang umum. Pasal 50 Undang-Undang Praktek Kedokteran Tahun 2004, sesuai dengan tanggung jawab profesi dokter spesialis dalam melaksanakan tindakan medis di klinik utama rawat inap sesuai hak dan kewajiban, berhak mendapakan perlindungan hukum artinya apabila dokter spesialis dalam melakukan tindakan medis di klinik utama sesuai dengan standar profesi dan standar pelayanan medis, dokter spesialis berhak mendapatkan pendampingan hukum. Akan tetapi apabila dokter spesialis dalam melakukan tindakan medik di klinik utama rawat inap tidak sesuai dengan standar profesi kedokteran dan standar pelayanan medis berarti dokter tersebut telah melakukan pelanggaran hukum, dalam istilah kedokteran medical malpractice.

Kode etik kedokteran yang berlaku di Indonesia berdasarkan falsafah Pancasila dan Undang-Undang Dasar 1945, yang telah disesuaikan dengan The International Code of Medical Ethics, sebagai pengemban tugas kemanusiaan dokter harus menjunjung tinggi kode etik dan sumpah dokter. Pada surat keputusan Pengurus Besar Ikatan Dokter Indonesia ( IDI ) Nomor III/PB/A.4.02/2013, pokok- pokok Kode Etik Kedokteran Indonesia ( KODEKI ) antara lain tentang hubungan dokter secara kemanusian, kewajiban umum, kewajiban dokter dengan pasien, kewajiban dokter dengan teman sejawat dan kewajiban dokter terhadap diri sendiri. Etika ini dibentuk oleh profesi secara kesadaran dan ketaatan untuk dilaksanakan peraturan yang diputuskan oleh profesi tersebut.

\footnotetext{
${ }^{13}$ Cecep Triwibowo, ibid. h .243
} 
Pertanggungjawaban dokter spesialis di klinik utama rawat inap tidak jauh dengan pertanggungjawaban di rumah sakit. Semua tindakan medis yang dilakukan di klinik utama rawat inap tidak hanya menjadi tanggung jawab pribadi dokter tetapi juga, rumah sakit seperti yang telah diatur dalam Undang-Undang Rumah Sakit pasal 34. Kewajban seorang dokter dalam mempertanggungjawabkan tindakannya sesuai pasal 51 Undang-Undang Praktek Kedokteran Tahun 2004 yang memiliki kewajiban salah satunya, memberikan pelayanan medis sesuai dengan standar profesi dan standar prosedur operasional serta kebutuhan medis pasien.

Pertanggungjawaban dikutip dari Roeslan Saleh menegaskan bahwa pertanggungjawaban itu dinyatakan dengan adanya hubungan antara kenyataan - kenyataan yang menjadi syarat dan akibat yang di syaratkan. Perlu dingat kembali bedanya unsur tindak pidana dan unsur-unsur pertanggung jawaban pidana. Pengertian tanggung jawab mengandung unsur-unsur: kecakapan, beban kewajiban, dan perbuatan. ${ }^{14}$ Dalam hal pertanggungjawaban pidana dokter spesialis dalam melakukan tindakan medis di klinik utama akan dibahas unsur - unsur tindak pidana. Syarat mutlak dokter sebelum melakukan tindakan menurut UndangUndang Praktek Kedokteran Pasal 29 dan Pasal 36 bahwa dokter harus memiliki STR dan SIP. Apabila syarat ini tidak terpenuhi maka, dokter tersebut telah melanggar larangan perbuatan pidana.

Tanggung jawab berikutnya ialah tanggung jawab dokter spesialis akibat melawan hukum (wederchtejilk) yang merupakan pelanggaran larangan yang bertentangan dengan hukum. Dalam menentukan perbuatan melawan hukum seorang dokter harus memenuhi kriteria 4 syarat, antara lain: a) Bertentangan dengan kewajiban si pelaku, b) Bertentangan dengan hak subyektif orang lain, c) Bertentangan dengan kesusilaan, dan d) Bertentangan dengan kepatutan, ketelitian dan kehatia-hatian. ${ }^{15}$ Klinik utama rawat inap dalam memberikan pelayanan kedokteran juga harus memperhatikan hak - hak pasien diantaranya hak atas penjelasan tentang penyakitnya, hak atas persetujuan tindakan dan hak atas informasi dari dokter yang merawat, apabila hal itu tidak dipenuhi oleh dokter spesialis dalam pelayanan medis di klinik utama rawat inap dokter akan di kenakan perbuatan melawan hukum sesuai undang - undang praktek kedokteran pasal 52. Dokter spesialis juga bertanggung jawab atas kesalahan yang dilakukan (schuld) yang terdiri dari kesengajaan (dollus atau opzet), kelalaian / kelapaan (negligence, culpa), dan tidak alasan pembenar atau pemaaf.

Hubungan hukum dokter dan pasien dari sudut pandang perdata berada dalam suatu perikatan hukum. Perikatan hukum adalah suatu ikatan antara dua atau lebih subjek hukum untuk melakukan atau tidak melakukan sesuatu atau memberikan sesuatu (1313 jo 1234 BW). Malpraktik kedokteran dari sudut perdata terjadi apabila perlakuan salah dokter dalam hubungannya dengan pemberian prestasi (dalam hal ini, prestasi adalah suatu kewajiban hukum bagi para pihak yang ,membuat perikatan hukum) menimbulkan kerugian keperdataan (diatur dalam hukum perdata). Perikatan hukum lahir oleh 2 (dua) sebab atau sumber, yang satu oleh suatu kesepakatan (1313 BW) dan yang lainnya oleh sebab Undang - Undang (1352 BW). Hubungan hukum dokter pasien berada dalam jenis perikatan hukum yang lahir sebab UU. Pelanggaran hukum dokter atas kewajiban hukum dokter karena UU membawa suatu keadaan perbuatan melawan hukum ( onrechtmatige daad ) dokter dimana kedua-duanya mengemban pertanggungjawaban penggantian kerugian.

Prinsip pertanggungjawaban dokter spesialis dalam hukum perdata terdiri dari pertanggungjawaban personal dan mandiri, pertanggungjawaban Zaakwarweening dokter spesialis, pertanggungjawaban kuasa (Volmacht) dokter spesialis, pertanggungjawaban Respondead Superior atau Vicarious Liability dokter spesialis, dan pertanggung jawaban wanprestasi dokter spesialis. Seorang dokter yang melakukan kesalahan dalam menjalankan fungsi independennya yang mengakibatkan kerugian pada pasien maka ia wajib memikul tanggungjawabnya secara mandiri. Kedua, dalam keadaan pertolongan darurat rumah sakit dapat melakukan tindakan medis tanpa harus ada persetujuan informed consent oleh pasien atau keluarganya. ${ }^{16}$ Apabila dilakukan tindakan medis tanpa informed consent dan pasien tidak mendapatkan hasil yang dinginkan namun dokter sudah melakukan dokter sesuai dengan standar pelayanan, SPO, dan kode etik kedokteran, maka sebagai tanggung jawab Zaakwaarneming dokter tidak dapat dituntut.

Pemberian kuasa menurut pasal 1792 BW, disebutkan bahwa pemberian kuasa adalah perjanjian dimana seseorang memberi kekuasaan ( kewenangan ) kepada orang lain yang menerimanya untuk dan atas nama pemberi kuasa melakukan perbuatan hukum (undang-undang mengatakan "melaksanakan suatu urusan" ). ${ }^{17}$ Dengan adanya rumusan pasal tersebut tersimpul bahwa untuk melaksanakan suatu perbuatan dalam hal ini tindakan medik yang dilimpahkan dokter spesialis kepada dokter umum atau dilimpahkan sesama dokter spesialis, pada dasarnya terdapat dua pihak yang saling berhadapan yakni pihak pemberi kuasa dalam hal ini dokter sebagai pihak yang mempunyai kepentingan dengan pihak yang diberi kuasa yaitu dokter umum atau dokter spesialis yang berkedudukan sebagai wakil yang menyelenggarakan kepentingan itu. Pihak yang diberi kuasa ini mempunyai peranan dan memiliki kekuasaan dalam menyelenggarakan urusan yang dilimpahkan kepadanya. ${ }^{18}$

Vicariaus liability, lazim disebut dengan pertanggungjawaban pengganti, diartikan sebagai pertanggungjawaban hukum seseorang atas perbuatan salah yang dilakukan oleh orang lain. ${ }^{19}$ Sesuai dengan teori atau doktrin respondeat superior bahwa antara dokter spesialis dan dokter umum terdapat hubungan kerja sama sesuai dengan tugas yang diberikan oleh klinik utama

\footnotetext{
${ }^{14}$ Muntaha ,Hukum Pidana Malpraktek Pertanggungjawaban dan Penghapus Pidana, Cetakan Pertama Sinar Grafika, Jakarta .2017.h.103

${ }^{15}$ Rosa Agustina. Perbuatan Melawan Hukum. Jakarta, Penerbit Pasca Sarjana FH Universitas Indonesia. 2003 h. 117

${ }^{16}$ Soerjono Soekamto (I) dan Kartono Mohamad, aspek Hukum dan etika kedokteran di Indonesia , Jakarta . Grafiti Pers.1983.h.69

${ }^{17}$ Suryodiningrat,Perikatan-Perikatan Bersumber Perjanjian, Bandung, Transito, 2011, h. 99.

${ }^{18}$ Wiryono Prodjodikoro, Hukum Perdata Persetujuan-Persetujuan Tertentu, Jakarta, Sumur Bandung, Cet. VII, 2014, h. 152.

${ }^{19}$ Mahrus Ali, Asas-Asas Hukum Pidana Korporasi dalam Russel Heaton, Criminal Law Textbook, Oxford University Press, London, 2006 , h. 403.
} 
rawat inap. ${ }^{20}$ Doktrin respondead superior ini mengandung arti bahwa seorang pimpinan klinik adalah seorang yang berhak memberikan intruksi dan mengontrol bawahnya, baik atas hasil yang dicapai maupun tentang cara yang di gunakan.

Hubungan dokter dan pasien lahir karena adanya hubungan kontraktual antara pasien dan dokter, pada pasal 1335 jo 1320 BW, dapat diartikan sebagai tujuan bersama yang hendak dicapai para pihak dalam hubungan kontraktual yang mereka buat. ${ }^{21}$ Sebagai bentuk khusus perikatan hukum timbal balik, perikatan hukum dokter-pasien yang dikenal sebagai kontrak terapeutik jaga saling membebani kewajiban untuk memberikan prestasi dan saling menerima prestasi antara dokter dan pasien. Bagi seorang dokter prestasi adalah upaya penyembuhan atau tidak berbuat kesalahan atau kekeliruan dalam perlakuan medis. Kontrak terapeutik antara dokter dan pasien bukan termasuk perjanjian resultaat vebertenis melainkan inspaning vebrtenis, pelayanan dokter yang ditujukan bukan dari hasil perbuatan melainkan hasil dari pelayanan dokter yang sesuai dengan standar pelayanan medis dan SPO. Wanprestasi dalam arti khilafah harfiah prestasi yang buruk, yang pada dasarnya melanggar isi kesepakatan dalam perjanjian kontrak oleh salah satu pihak.

Berikutnya, dokter spesialis juga memiliki tanggung jawab secara hukum administrasi. Hukum administrasi adalah hal-hal yang secara khusus mengatur hubungan timbal balik antara pemerintah dan rakyat sehingga titik berat objek ada pada hubungan istimewa tersebut sehingga perlu ada dalam norma peraturan. ${ }^{22}$ Penyelenggaraan praktik kedokteran sesuai dengan pasal 36 Undang-Undang Nomor 29 Tahun 2004 Tentang Praktik Kedokteran, menyatakan bahwa :"Setiap dokter dan dokter gigi yang melakukan praktik kedokteran di Indonesia wajib memiliki surat izin praktik". Pasal 1 ayat (1) Permenkes Nomor 2052/Menkes/Per/X/2011 Tentang Izin Praktik Dan Pelaksanaan Praktik Kedokteran, menyatakan bahwa :"Praktik kedokteran adalah rangkaian kegiatan yang dilakukan oleh dokter terhadap pasien dalam melaksanakan upaya kesehatan". Pada penyelenggaraan praktik kedokteran, dokter yang membuka praktik kedokteran atau layanan kesehatan harus memenuhi persyaratan yang ditetapkan pemerintah, antara lain: 1) Memiliki Surat Tanda Registrasi (STR) dan 2) Surat Izin Praktik Dokter (SIP).

\section{III.PENUTUP}

\section{A. Kesimpulan}

Kewenangan dokter spesialis dalam menjalankan tugasnya harus berpegang teguh pada standar profesi, standar kompetensi dokter spesialis serta mempunyai prinsip dasar etika kedokteran Dokter spesialis dalam melakukan tindakan medis di klinik utama rawat inap mendapat kewenangan secara altribusi yaitu sebagai profesi dokter spesialis menjalankan tugasnya berdasarkan perintah atau peraturan perundang-undangan.

Pelayanan kedokteran pada pasien bertanggung jawab selama 24 jam supaya pelayanan pada pasien tetap berjalan secara maksimal dokter harus bekerja secara tim. Dalam hal ini diperlukan mekanisme pelimpahan wewenang dengan pelimpahan wewenang secara mandat yaitu dari dokter spesialis kepada dokter umum atau bawahanya yang mempunyai kompetensi sesuai keahlianya. Kewenangan delegasi melengkapi pelimpahan wewenaang apabila dokter spesialis berhalangan datang dengan pelimpahan secara delegasi ini, maka yang bertanggung jawab adalah dokter yang menerima delegasi.

Menurut UU Praktek Kedokteran No. 9 Tahun 2004 bahwa dokter spesialis yang memiliki STR, SIP, memiliki surat keterangan surat mental dan fisik, serta memiliki kompetensi mempunyai kewenangan yang melekat pada profesi seorang dokter spesialis. Menurut PMK No. 9 tahun 2014 bahwa dokter spesialis bedah dalam melakukan tindakan operasi ringan dan sedang tidak beresiko, sedangkan dokter spesialis anaestesi dalam mendukung tindakan dokter spesialis bedah di klinik utama sesuai kompetensi yang dimiliki oleh dokter spesialis adalah anestesi lokal, anaestesi regional, anestesi general.

Tanggung jawab dokter spesialis dalam melakukan tindakan medis di klinik utama rawat inap menurut hukum adalah sebagai konsekuensi suatu akibat perbuatan yang berkaitan dengan etika dan perilaku suatu perbuatan, dalam melakukan tindakan medis dokter spesialis menpunyai tanggung jawab secara profesi dalam mengemban jabatannya, secara etik dan dispilin kedokteran sebagai seorang dokter harus menjunjung tinggi sumpah kedokteran dan tugas kemanusiaan yang berbudi luhur. Tanggung jawab pidana dokter spesialis meliputi unsur - unsur pidana, diantaranya perbuatan pidana, perbuatan melawan hukum dan kesalahan yang patut di pidanakan. Adapun tanggung jawab dokter spesialis dari unsur kesalahan adalah adanya kesengajaan, kelalaian, dan tidak ada alasan pemaaf dan pembenar. Dokter spesialis dalam melakukan tindakan medis terdapat pada kitab undang-undang pasal 1313 BW dan 1352 BW tentang perikatan dan kesepakatan. Pelanggaran hukum dokter dalam kewajiban undang - undang membawa suatu perbuatan melawan hukum (onrechtmatige daad) di mana mengemban suatu pertanggung jawaban pergantian kerugian. Ganti rugi yang di emban oleh dokter spesialis dalam hukum perdata terdapat empat prinsip pertanggung jawaban yaitu, pertanggungjawaban mandiri (personal liability), pertanggungjawaban zaakwarweening, pertanggungjawaban kuasa (volmacht), pertanggungjawaban responded superior, dan pertanggungjawaban wanprestasi.Sementara, tanggung jawab hukum adminitrasi merupakan tanggung jawab yang harus dipenuhi dalam

\footnotetext{
${ }^{20}$ H. Syahrul Machmud, Penegakan Hukum dan Perlindungan Hukum Bagi Dokter Yang Diduga MelakukanMedikal Malpraktek, Karya Putra Darwati. Cet. I, Bandung,2012. H 17.

${ }^{21}$ Agus Yudha Heernoko,Hukum perjanjian Azas porposionalitas Dalam Kontrak kormesial, Jakarta.Pt

Kharisma Putra Utama. Edisi Pertama 2010 .h.225

${ }_{22}^{2}$ Yos Johan Utama, Pengertian Administrasi Negara dan Hukum Administrasi Negara, Modul 1 Tahun 2014.
} 
Website : http://yustisia.unmermadiun.ac.id/index.php/yustisia

melaksanakan praktek kedokteran apabila tidak di penuhi secara administratif berarti sudah melanggar UU dan perbuatan melawan hukum.

\section{B. Saran}

Peneliti merekomendasikan peninjauan kembali terhadap kewenangan dokter spesialis dalam melakukan tindakan medis di klinik utama rawat inap pada PMK Nomor 9 tahun 2014 pasal 33 dan pasal 34 ayat (1), (2), (3) tentang kewenangan dokter anestesi dan dokter spesialis bedah. Kementerian Kesehatan Republik Indonesia dengan organisasi IDI perlu bersikap tegas dalam pembuatan peraturan perundang-undangan. PMK yang baru harus dibuat secara jelas dan tegas tentang klasifikasi klinik serta tindakan dokter spesialis di klinik utama rawat inap. Peneliti memberikan saran perlu adanya undang-undang yang mengatur tentang klasifikasi klinik dan jumlah tenaga medis yang memberikan pelayanan di klinik pratama maupun klinik utama. Peralatan yang harus dilengkapi di klinik utama rawat inap harus sesuai dengan tindakan dokter spesialis sebagai sarana yang menunjang tindakan dokter spesialis, bahwa kompetensi dan keahlian yang sifatnya melekat sesuai peraturan perundang undangan yang berlaku di Indonesia.

\section{IV.DAFTAR PUSTAKA}

Muhamad Sadi Is, Etika dan Hukum Kesehatan, Kencana Prenadamedia Group, Jakarta, 2015, h. 7

Kementerian Kesehatan Republik Indonesia, Profil kesehatan Indonsia tahun 2016, Jakarta, Kementerian Kesehatan Republik Indonesia. 2017, h.75

Muntaha, Hukum Pidana Malpraktek Pertanggungjawaban dan penghapus Pidana, Sinar Grafika, Jakarta Timur, 2017, h.53

Lutfi Effendi, Pokok-pokok Hukum Administrasi, Cetakan III, Bayumedia, Malang, 2004, h .77- 79

Ridwan Syahrani, Seluk Beluk dan Asas-Asas Hukum Perdata, Bandung, Cet 4, Pt.Alumni, 2000, h. 2.

Sri Supraptiningsih, Kedudukan Hukum Perawat dalam Upaya Pelayanan Kesehatan di Rumah Sakit. Rajagrafindo Persada, Jakarta, 2006, h 126.

H.Zainudin Ali,M.A, Metode Penelitian Hukum ,Sinar Grafika . Jakarta 2015 h. 25-26

Mertokusumo Sudikno, Penemuan Hukum, Liberty, Yogjakarta 2007, h.18.

Marzuki Peter Mahmud, Penelitian Hukum, Kencana Prenada Media Group, Jakarta 2005, h.59-60.

Wila Chandrawila Supriadi, Hukum Kedokteran,.Mandar Maju .Bandung .2001. h 5

Ibid. h.104.

J. Guwandi, Hukum Medik (Medical Law), Fakulatas Kedokteran Universitas Jakarta, 2004. h. 225.

Cecep Triwibowo, ibid. h .243

Rosa Agustina. Perbuatan Melawan Hukum. Jakarta, Penerbit Pasca Sarjana FH Universitas Indonesia. 2003 h.117

Soerjono Soekamto (I) dan Kartono Mohamad, aspek Hukum dan etika kedokteran di Indonesia , Jakarta . Grafiti Pers.1983.h.69

Suryodiningrat,Perikatan-Perikatan Bersumber Perjanjian, Bandung, Transito, 2011, h. 99.

Wiryono Prodjodikoro, Hukum Perdata Persetujuan-Persetujuan Tertentu, Jakarta, Sumur Bandung, Cet. VII, 2014 , h. 152.

Mahrus Ali, Asas-Asas Hukum Pidana Korporasi dalam Russel Heaton, Criminal Law Textbook, Oxford University Press, London, 2006 , h. 403.

H. Syahrul Machmud, Penegakan Hukum danPerlindungan Hukum Bagi Dokter Yang Diduga MelakukanMedikal Malpraktek, Karya Putra Darwati. Cet. I, Bandung,2012. H 17. 